\title{
Editorial
}

\section{Patrick Rysiew}

This special issue of Philosophical Studies consists of a selection of papers and Author-Meets-Critics sessions presented at the 2013 meeting of the Pacific Division of the American Philosophical Association in San Francisco. Members of the 2012-2013 Program Committee chose the papers for presentation and offered recommendations for publication. The members of that committee are:

Patrick Rysiew, Chair

Chrisoula Andreou

Neera Badhwar

Tim Black

Elizabeth Brake

Juan Comesaña

Philip Corkum

Angela Coventry

Sharon Crasnow

Jeremy Fantl

Patrick R. Frierson

Jeff Gauthier

Franz-Peter Griesmaier

Cindy Holder

Carrie Ichikawa Jenkins

Pierre Keller

Krista Lawlor

Darrel Moellendorf
Graham Oddie

Marina Oshana

David Pitt

Lisa Raphals

Samuel Rickless

Peter Ross

Nancy E. Snow

Janet Stemwedel

Brad Elliott Stone

Ásta Sveinsdóttir

Jan Szaif

Kenneth Taylor

Kevin L. Timpe

Shelley Wilcox

Robert A. Wilson

Audrey Yap

Richard Zach

P. Rysiew ( $\square$ )

Department of Philosophy, The University of Victoria, P.O. Box 3045, Victoria,

BC V8W 3P4, Canada

e-mail: rysiew@uvic.ca 